\title{
FINANCIAL PERFORMANCE OF SELECT SOFTWARE COMPANY IN INDIA -AN ANALYTICAL STUDY
}

\author{
Dr. K. Jagadeesan \\ Ph.D. Assistant Professor of Commerce, Government Arts College (A), \\ Affiliated to Bharathidasan University, Kumbakonam, Tamilnadu - 612002 \\ E-mail:mskpubs@gmail.com

\section{Mrs. K. Malarvizhirekha} \\ Research Scholar (Part-Time), PG and Research Department of Commerce, \\ Government Arts College (Autonomous), Affiliated to Bharathidasan University, \\ Kumbakonam-02
}

\begin{abstract}
Information Technology in India is an industry consisting of two major components: IT services and business process outsourcing(BPO). ${ }^{[1]}$ The sector has increased its contribution to India's GDP from 1.2\% in 1998 to 7.7\% in 2017. India's IT Services industry was born in Mumbai in 1967 with the creation of Tata Consultancy Services ${ }^{[7]}$ who in 1977 partnered with Burroughs which began India's export of IT services. Objectives of the study, 1. To analyze the financial performance of selected software companies in terms of liquidity and solvency, positions and to assess the working capital position of selected software companies in India. Methodology of the study, Secondary data is used for the study which is obtained from concerned companies" website, NSE website and also from other relevant sites. Ten companies were selected as sample size, on the basis of convenient sampling technique. To analyze the performance of the selected companies, various techniques have been applied, like ratio analysis, mean, standard deviation, coefficient of variation and CAGR Suggestions of the study, The burden of interest has produced a deteriorating effect and reduced the percentage of net profit. It is suggested that a study of productivity and financial efficiency of the software industry of Indian companies. The few companies, which did not follow a definite policy of financing fixed assets, should follow such policy.
\end{abstract}

Keywords: Liquidity, solvency, finance etc. 


\section{I.1. INTRODUCTION}

Information Technology in India is an industry consisting of two major components: IT services and business process outsourcing (BPO) ${ }^{[1]}$ The sector has increased its contribution to India's GDP from $1.2 \%$ in 1998 to $7.7 \%$ in $2017 .{ }^{[2]}$ According to NASSCOM, the sector aggregated revenues US $\$ 180$ billion in $2019,{ }^{[3][4]}$ with export revenue of standing at US\$99 billion and domestic revenue at US $\$ 48$ billion, growing by over 13\%. As of 2020, India's IT workforce accounts for 4.36 million employees. ${ }^{[5]}$ The United States accounts for two-thirds of India's IT services exports.

\section{I.2. HISTORY OF IT COMPANY}

India's IT Services industry was born in Mumbai in 1967 with the creation of Tata Consultancy Services ${ }^{[7]}$ who in 1977 partnered with Burroughs which began India's export of IT services. ${ }^{[8]}$ The first software export zone, SEEPZ - the precursor to the modern-day IT park - was established in Mumbai in 1973. More than 80 percent of the country's software exports were from SEEPZ in the 1980s. ${ }^{[9]}$

Within 90 days of its establishment, the Task Force produced an extensive background report on the state of technology in India and an IT Action Plan with 108 recommendations. The Task Force could act quickly because it built upon the experience and frustrations of state governments, central government agencies, universities, and the software industry. Much of what it proposed was also consistent with the thinking and recommendations of international bodies like the World Trade Organization (WTO), International Telecommunications Union (ITU), and World Bank. In addition, the Task Force incorporated the experiences of Singapore and other nations, which implemented similar programs. It was less a task of invention than of sparking action on a consensus that had already evolved within the networking community and government.

In 1991 the Department of Electronics broke this impasse, creating a corporation called Software Technology Parks of India (STPI) that, being owned by the government, could provide VSAT communications without breaching its monopoly. STPI set up software technology parks in different cities, each of which provided satellite links to be used by firms; the local link was a wireless radio link. In 1993 the government began to allow individual companies their own dedicated links, which allowed work done in India to be transmitted abroad directly. Indian firms soon convinced their American customers that a satellite link was as reliable as a team of programmers working in the clients' office.

A joint EU-India group of scholars was formed on 23 November 2001 to further promote joint research and development. On 25 June 2002, India and the European Union agreed to bilateral cooperation in the field of science and technology. From 2017, India holds a Associate Member State status at CERN, while a joint India-EU Software Education and Development Center will be located in Bangalore 
The Indian Information Technology/ Information Technology Enabled Services (IT/ITeS) industry is a global powerhouse today, and its impact on India has been incomparable. It has contributed immensely in positioning the country as a preferred investment destination amongst global investors and creating hug job opportunities in India, as well as in the USA, Europe and other parts of the world. In the last decade, the industry has grown five fold in revenue terms, and relative share to India's GDP has increased to $>7.9$ percent in FY2017-18. India is the topmost off-shoring destination for IT companies across the world. Having proven its capabilities in delivering both on-shore and off-shore services to global clients, emerging technologies now offer an entire new gamut of opportunities for top IT firms in India. The country's cost competitiveness in providing IT services, which is approximately 3-4 times cheaper than the US, continues to be its Unique Selling Proposition (USP) in the global sourcing market. Indian IT-ITeS industry offers cost-effectiveness, great quality, high reliability, speedy deliveries and, above all, the use of state-of-the-art technologies globally.

Indian global sourcing market growth continues to outperform IT-BPM industry growth. During 2017-18, the global IT-ITeS market grew to US\$ 1.3 trillion (excl. hardware) and global sourcing market increased by 1.4 times to reach US\$ $185-190$ billion. India continued as the world's top sourcing destination with a significant share of 55\%. Indian ITITeS industry has set up over 1000 global delivery centres in over 200 cities in about 80 countries around the world. The Ministry of Electronics and Information Technology is coordinating strategic activities, promoting skill development programmes, enhancing infrastructure capabilities and supporting R\&D for India's leadership position in IT and ITenabled Services.

\section{I.3.REVIEW OF LITERATURE}

Jeevan Jayant Nagarkar (2015) in his study on financial performance analysis of India banks, divides the period of 10 years from 2002 to 2013 on the basis of growth rate of banks, the first five years has high growth rate followed with slogging rate. Slow down in the growth of credit, improper check of credit appraisal process, granting advances from borrowing are few reason for slow growth rate, however large banks are not affected much due to their virtue. Thus government's decision of merging small banks is justified in the study.

Ravichandran (2016), studied financial performance of Force Motors with the main objective to identify the individual ratios which are affecting the profitability of the industry and to categorized the financial ratios into a small number of latent variable to represent a compact view of financial performance for a specified time period. The study revealed that the financial performance was fair and it has been maintaining good, further improvement can be done by concentrating on its operating, administrative and selling expenses and thereby reducing expenses. 


\section{I.4. STATEMENT OF THE PROBLEM}

Business organizations will contribute towards economic development only when it is financial sound. Financial health of a firm can be measured through its financial performance. Financial Performance is measured by using various tools like Financial Statement Analysis, Ratio Analysis and Funds Flow Statement etc. Ratio Analysis is one of the popular tools used for analyzing the financial performance by researchers. It involves regrouping of data by application of arithmetical relationships and recognizes the profitability, liquidity, solvency and efficiency of the business. It helps in decision making through analysis and interpretation.

Software companies is in the spot light of Indian economy, creating more jobs, contributing to exports, attracting foreign investments etc, It calls for financial analysis to understand the reasons for the above. Financial analysis is helpful to know the financial strength and weakness of the firm and take proper decision. Meager accounting figures reported in the financial statements does not provide a meaningful insight on the performance and financial position of the firm, the study is concerned on analysis the liquidity, solvency, activity and profitability position to evaluate the financial performanc.

\section{I.5. OBJECTIVES OF THE STUDY}

1. To analyze the financial performance of selected software companies in terms of liquidity and solvency, positions.

2. To assess the working capital position of selected software companies in India

\section{I.6.METHODOLOGY OF THE STUDY}

Analytical research is undertaken with the help of data available in the companies ${ }^{\text {ee }}$ financial statements and analysis is done to find the financial health. Companies under observation were classified into three categories on the basis of market capitalization as per NSE values. Secondary data is used for the study which is obtained from concerned companies $^{\text {ee }}$ website, NSE website and also from other relevant sites. Ten companies were selected as sample size, on the basis of convenient sampling technique. To analyze the performance of the selected companies, various techniques have been applied, like ratio analysis, mean, standard deviation, co-efficient of variation and CAGR. The data collected for this study were obtained through the Secondary source. The data used for analysis were extracted from the audited annual financial reports and accounts of the sampled IT Companiescompanies for the period (2010-11 to 2019-20.). The researcher has chosen a sample of ten (10) software companies have been used in the study. The sampled companies are: TCS, Infosys, Wipro, HCL, Tech Mahendra, Oracle, MphasiS Ltd, Mindtree and so on.

\section{I.7.LIMITATIONS OF THE STUDY}

The sample size is limited to 10 companies and only secondary data is used, thus the study has inbuilt the limitations of secondary data. The period of study was limited to ten years. 


\section{I.8.DATA ANALYSIS}

MEAN: One of the most important objectives of statistical analysis is to get one single value that describes the characteristic of the entire mass of unwieldy data.

STANDARD DEVIATION: The standard deviation measures the absolute dispersion, the greater standard deviation, for the greater will be the magnitude of the deviation means a high degree of uniformity of the observation and the large standard deviation, for the large will be the magnitude of the deviation means a low degree of uniformity of the observation.

CO-EFFICIENT OF VARIATION: The corresponding relative measure is known as the coefficient variation. That series for which the coefficient of variation is greater is said to be more variable or conversely less consistent and less is said to be more consistent.

ANNUAL COMPOUND GROWTH RATE (CGR): The compound growth rate measures average growth of an amount over time. In other words, the compound growth rate assumes a constant rate of growth, thus smoothing the expansion rate. The advantage of the compound growth rate is that it expresses growth as one number. The downside of the compound growth rate is that it can hide sharp growth fluctuations.

\section{I.9.ANALYSIS AND INTERPRETRATION}

TABLE NO.1

CURRENT ASSETS OF SELECT SOFTWARE COMPANY

\begin{tabular}{|c|c|c|c|c|c|}
\hline & \multicolumn{5}{|c|}{ current Assets } \\
\hline Name of the company & Mean & S.D & $\mathrm{CV}$ & RANGE & $\begin{array}{l}\text { CAGR } \\
(\%)\end{array}$ \\
\hline $\mathrm{HCL}$ & 21486.02 & 9781.292 & 45.52398 & 31763.37 & 978129.2 \\
\hline INFOSYS & 44285.6 & 10828.46 & 24.45142 & 30573 & 1082846 \\
\hline HEXAWARE & 1219.348 & 395.7118 & 32.45273 & 1196.97 & 39571.18 \\
\hline MINDTREE & 1847.76 & 829.4512 & 44.88955 & 2616.1 & 82945.12 \\
\hline LASEN \& TURBO & 108852.9 & 43081.69 & 39.57789 & 130109.2 & 4308169 \\
\hline MPHASIS LIMITED & 3960.213 & 473.1669 & 11.94802 & 1322.64 & 47316.69 \\
\hline REDINTON & 8600.032 & 2903.822 & 33.76525 & 8855.38 & 290382.2 \\
\hline TCS & 57140.64 & 28246.67 & 49.43359 & 75094.59 & 2824667 \\
\hline TECH MAHINDRA & 12428.19 & 7862.3 & 63.26183 & 21143.3 & 786230 \\
\hline WIPRO & 37841.25 & 9966.43 & 26.33748 & 27014.9 & 996643 \\
\hline
\end{tabular}

Source: CMIE

The current assets of the sample software companies was shown in 1, The mean value was the highest in Larsen \& Turbo Ltd., i.e., 108852.9 followed by TCS Companies i.e., 57140.64, Current assets of all the selectedsoftware companies reflected that they were below the current assets in most of the years. Hence, it could be concluded that the current assests was not in a satisfactory position in all the companies. The range of current assests which worked out as 130109.2 of Larsen \& Turbo Ltd., showed the highest among the selected software companies in India for the present study. The compound annual growth rate 
of Larsen \& Turbo Ltd., had the highest growth rate (4308169), while there was a slowly growth rate in the other selected software companies.

The co-efficient of variation showed that the current Assets of Mphasis Limited was more consistent (11.94802) than the other companies and it was followed by infosys, wipro, Hexware, and redinton and so on.

Table No.2

CURRENT LIABILITIES

\begin{tabular}{|l|r|l|l|r|l|}
\hline & \multicolumn{5}{|c|}{ current Liabilities } \\
\hline & \multicolumn{1}{|c|}{ Mean } & \multicolumn{1}{|c|}{ S.D } & CV & RANGE & $\begin{array}{l}\text { CAGR } \\
(\%)\end{array}$ \\
\hline HCL & \multicolumn{1}{|c|}{10444.63} & 5256.088 & 50.32335 & 19666.18 & 141.6471 \\
\hline INFOSYS & 12861 & 4994.335 & 38.83318 & 15632 & 14.84783 \\
\hline HEXAWARE & 559.314 & 264.0545 & 47.21043 & 934.56 & 15.85386 \\
\hline MINDTREE & 671.89 & 338.4309 & 50.36999 & 1110 & 20.00948 \\
\hline LASEN \& TURBO & 84741.59 & 35763.01 & 42.20243 & 106188.4 & 14.14676 \\
\hline MPHASIS LIMITED & 1537.2 & 334.802 & 21.77999 & 1078.57 & 4.485714 \\
\hline REDINTON & 6011.779 & 2024.703 & 33.67892 & 6222.44 & 10.86105 \\
\hline TCS & 16132.15 & 5734.069 & 35.54436 & 19813.97 & 14.08348 \\
\hline TECH MAHINDRA & 5736.45 & 3304.088 & 57.59813 & 9415.3 & 21.88023 \\
\hline WIPRO & 14711.68 & 2191.833 & 14.89859 & 7040.7 & 4.764199 \\
\hline
\end{tabular}

\section{Source: CMIE}

The current liabilities of the sample software companies was shown in 2, The mean value was the highest in Larsen \& Turbo Ltd., i.e., 84741.59 followed by TCS Companies i.e., 16132.15, Wipro companies 14711.68 Current liabilities of all the selectedsoftware companies reflected that they were high the in most of the years. Hence, it could be concluded that the current liabilities was high, hence not satisfactory position in all the companies. The range of current liabilities which worked out as 106188.4 of Larsen \& Turbo Ltd., showed the highest among the selected software companies in India for the present study. The compound annual growth rate of Larsen \& Turbo Ltd., had the highest growth rate (14.14676), while there was a high growth rate in the other selected software companies. The co-efficient of variation showed that the current liabilities of Wipro Limited was more consistent (14.89859) than the other companies and it was followed by Mphasis Limited,Redinton,TCS,Infosys, Larsen \& ,Turbo,Hexaware,Hcl,Mindtree and Tech Mahindra

TABLE NO. 3

CURRENT RATIO

\begin{tabular}{|l|r|r|r|r|r|}
\hline & \multicolumn{5}{|c|}{ CURRENT RATIO } \\
\hline Name of the company & \multicolumn{1}{|c|}{ Mean } & \multicolumn{1}{l|}{ S.D } & \multicolumn{1}{l|}{ CV } & \multicolumn{1}{l|}{ Ranige } & \multicolumn{1}{c|}{ CAGR } \\
\hline HCL & 2.049 & 0.418 & 20.390 & 1.133 & -0.001 \\
\hline INFOSYS & 3.671 & 0.679 & 18.485 & 1.978 & -0.055 \\
\hline HEXAWARE & 2.315 & 0.484 & 20.908 & 1.417 & -0.067 \\
\hline MINDTREE & 2.832 & 0.355 & 12.538 & 0.983 & -0.019 \\
\hline LASEN \& TURBO & 1.301 & 0.070 & 5.346 & 0.183 & -0.008 \\
\hline
\end{tabular}




\begin{tabular}{|l|r|r|r|r|r|} 
MPHASIS LIMITED & 2.676 & 0.655 & 24.459 & 2.070 & -0.025 \\
\hline REDINTON & 1.430 & 0.032 & 2.246 & 0.098 & 0.001 \\
\hline TCS & 3.433 & 1.149 & 33.478 & 3.315 & 0.036 \\
\hline TECH MAHINDRA & 1.998 & 0.535 & 26.788 & 1.522 & 0.047 \\
\hline WIPRO & 2.561 & 0.538 & 21.012 & 1.760 & 0.028 \\
\hline
\end{tabular}

Source: CMIE

The current ratio of the sample software companies was shown in 3, The mean value was the highest in Infosys i.e., 3.671.59 followed by TCS Companies i.e., 3.433, mind tree companies 2.832 Current ratio of all the selectedsoftware companies reflected that they were high the in most of the years except tech mahindra, larsen and Turbo and Redinton. Hence, it could be concluded that the current ratio was high, only three companies current ratio e not satisfactory position. The range of current ratio which worked out as 1.978 of TCS ratio of 3.315., showed the highest among the selected software companies in India for the present study. The compound annual growth rate of Tech mahindra, had the highest growth rate $(0.047)$, while there was a high growth rate in the other selected software companies. The co-efficient of variation showed that the current ratio of Redinton, was more consistent (2.246) than the other companies and it was followed by Larsen \& Turbo, Mindtree, Infosys, HCL, Hexware, Wipro, Mphasis Limited, Tech mahindra nd TCS

TABLENO.4 QUICK RATIO

\begin{tabular}{|l|r|r|r|r|r|}
\hline Name of the company & \multicolumn{1}{l|}{ Mean } & \multicolumn{1}{l|}{ S.D } & \multicolumn{1}{l|}{ CV } & \multicolumn{1}{l|}{ RANGE } & \multicolumn{1}{l|}{ CAGR } \\
\hline HCL & 2.027 & 0.421427 & 20.7907 & 1.14 & 0.006231 \\
\hline INFOSYS & 3.671 & 0.675614 & 18.40409 & 1.97 & -0.05453 \\
\hline HEXAWARE & 2.316 & 0.484841 & 20.93443 & 1.42 & -0.06697 \\
\hline MINDTREE & 2.833 & 0.354528 & 12.51422 & 0.98 & -0.01932 \\
\hline LASEN \& TURBO & 1.289 & 0.158916 & 12.32866 & 0.57 & -0.00556 \\
\hline MPHASIS LIMITED & 2.677 & 0.65488 & 24.4632 & 2.07 & -0.02508 \\
\hline REDINTON & 0.958 & 0.050728 & 5.295202 & 0.17 & 0.010265 \\
\hline TCS & 3.433 & 1.148836 & 33.46448 & 3.31 & 0.03547 \\
\hline TECH MAHINDRA & 2.022 & 0.558188 & 27.60571 & 1.52 & 0.046943 \\
\hline WIPRO & 2.197 & 0.268951 & 12.24172 & 0.85 & 0.025942 \\
\hline
\end{tabular}

\section{Source: CMIE}

The quick ratio of the sample software companies was shown in 4, The mean value was the highest in Infosys i.e., 3.671 .59 followed by TCS Companies i.e., 3.433, Mind tree companies 2.833 Quick ratio of all the selected software companies reflected that they were high the in most of the years except and Redinton. Hence, it could be concluded that the quick ratio was high, only one companies quick ratio not satisfactory position. The range of quick ratio which worked out as of TCS ratio of 3.31., showed the highest among the selected software companies in India for the present study. The compound annual growth rate of Tech mahindra, had the highest growth rate $(0.047)$, while there was a 
high growth rate in the other selected software companies. The co-efficient of variation showed that the quick ratio of Redinton, was more consistent (0.17) than the other companies and it was followed by Wipro, Lasen \& urbo, Mindtree, Infosys, Hcl, Hexaware, Mphasis Limited, Tech Mahindra and TCS

TABLE NO.5 WORKING CAPITAL OF SELECT SOFTWARE COMPANIES

\begin{tabular}{|l|r|r|r|r|r|}
\hline Name of the company & \multicolumn{1}{l|}{ Mean } & \multicolumn{1}{l|}{ S.D } & \multicolumn{1}{l|}{ CV } & \multicolumn{1}{l|}{ Ranige } & \multicolumn{1}{l|}{ CAGR } \\
\hline HCL & 10282.16 & 7507.557 & 73.015 & 23679.04 & -0.346 \\
\hline INFOSYS & 11434.72 & 7297.18 & 63.816 & 20839.46 & -0.500 \\
\hline HEXAWARE & 535.5202 & 371.6196 & 69.394 & 1196.268 & -0.305 \\
\hline MINDTREE & 687.822 & 433.7635 & 63.063 & 1301.742 & -0.309 \\
\hline LASEN \& TURBO & 78911.1 & 51101.47 & 64.758 & 144713.9 & -0.582 \\
\hline MPHASIS LIMITED & 1074.53 & 758.1695 & 70.558 & 2162.078 & -0.466 \\
\hline REDINTON & 5260.783 & 3365.438 & 63.972 & 9659.348 & -0.478 \\
\hline TCS & 13751.78 & 9021.435 & 65.602 & 27045.8 & -0.517 \\
\hline TECH MAHINDRA & 5969.393 & 3903.546 & 65.393 & 10903.44 & -0.430 \\
\hline WIPRO & 10056.67 & 6975.663 & 69.364 & 16438.24 & -0.574 \\
\hline
\end{tabular}

Source: CMIE

The working capital of the sample software companies was shown in 5, The mean value was the highest in Larson and Turbo i.e., 78.911 followed by TCS Companies i.e., 13.751, Infosys companies 11.434 working capital of all the selected software companies reflected that they were high the in most of the years except three Mphasis, Mindtree, Hexware. Hence, it could be concluded that the working capital was high, except three company's working capital not satisfactory position. The range of working capital which worked out as of Larson \& Turbo ratio of 144.713., showed the highest among the selected software companies in India for the present study. The compound annual growth rate of Mind tree had the highest growth rate (-0.039), while there was a high growth rate in the other selected software companies. The co-efficient of variation showed that the working capital of Mindtree, was more consistent (63.063) than the other companies and it was followed by Infosys, Redinton, Larsen \& turbo, Tech mahindra, TCS, wipro, hexaware, mphasis limited and HCL 
TABLE NO.6

RETURN ON CAPITAL EMPLOYED RATIO

\begin{tabular}{|l|r|r|r|r|l|}
\hline \multicolumn{7}{|c|}{ Mame of the company } & Mean & S.D & CV & RANGE & CAGR \\
\hline HCL & 27.993 & 5.397318 & 19.28096 & 18.97 & 0.18724985 \\
\hline INFOSYS & 26.952 & 3.476351 & 12.89831 & 10.12 & 0.01636722 \\
\hline HEXAWARE & 28.182 & 6.764359 & 24.00241 & 25.28 & 0.11144228 \\
\hline MINDTREE & 22.591 & 5.160182 & 22.84176 & 17.09 & 0.06135546 \\
\hline LASEN \& TURBO & 7.129 & 2.469338 & 34.63794 & 6.69 & 0.02274557 \\
\hline MPHASIS LIMITED & 15.549 & 6.229138 & 40.06134 & 19.3 & 0.01709776 \\
\hline REDINTON & 15.568 & 2.950302 & 18.95107 & 7.98 & 0.02790622 \\
\hline TCS & 37.964 & 4.437728 & 11.6893 & 13 & 0.02581685 \\
\hline TECH MAHINDRA & 20.607 & 3.51259 & 17.04562 & 12.48 & 0.03443845 \\
\hline WIPRO & 20.828 & 1.750364 & 8.403898 & 5.56 & 0.00313234 \\
\hline
\end{tabular}

Source: CMIE

TABLE NO.7

DEBT EQUITY RATIO

\begin{tabular}{|l|r|r|r|r|}
\hline Name of the company & \multicolumn{1}{l|}{ Mean } & \multicolumn{1}{l|}{ S.D. } & C.V.(\%) & $\begin{array}{l}\text { CAGR } \\
(\boldsymbol{\%})\end{array}$ \\
\hline HCL & 0.07 & 0.07 & 98.38 & -36.04 \\
\hline INFOSYS & - & - & 0 & 0 \\
\hline HEXAWARE & 0.01 & 0.02 & 262.94 & 17.46 \\
\hline MINDTREE & 0.03 & 0.03 & 138.88 & -100 \\
\hline LASEN \& TURBO & 1.78 & 0.33 & 18.3 & 6.26 \\
\hline MPHASIS LIMITED & 0.08 & 0.02 & 28.28 & 3.63 \\
\hline REDINTON & 0.82 & 0.41 & 50.06 & -7.38 \\
\hline TCS & 0 & 0 & 161.02 & 0 \\
\hline TECH MAHINDRA & 0.13 & 0.11 & 83.58 & -10.93 \\
\hline WIPRO & 0.2 & 0.05 & 25.44 & -7.11 \\
\hline
\end{tabular}

\section{Source: CMIE}

The Return on Capital employed of the sample software companies was shown in 6, The mean value was the highest in Larson and Turbo i.e., 37.964 followed by Hexware Companies i.e., 28.182, HCL companies 27.993 Return on Capital employed of all the selected software companies reflected that they were high the in most of the years except Larson and Turbo. Hence, it could be concluded that the Return on Capital employed was high, except one companies. The range of Return on Capital employed which worked out as of Hexware ratio of 25.28., showed the highest among the selected software companies in India for the present study. The compound annual growth rate of HCL had the highest growth rate 0.187 ), while there was a high growth rate in the other selected software companies. The co-efficient of variation showed that the Return on Capital employed of wipro was more 
consistent (8.403898) than the other companies and it was followed by TCS, Infosys, Tech Mahindra, Redinton, HCL, Mindtree, Hexaware, Lasen \& Turbo And Mphasis Limited

The mean value of the Debt equity ratio of HCL Limited was 0.07 and co-efficient of variation was 98.38 per cent. By observing the co-efficient of variation, the variation of current ratio was lower during the study period except during the year 2010-11. On the other hand the mean value of the Debt equity ratio of Hexware Limited was 0.01 and co-efficient of variation was 262.94 per cent. It was observed from the co-efficient of variation of the Mindtree Limited was 0.03 and co-efficient of variation was 138.88 per cent. It could be observed from the co-efficient of variation of the Lasen @ Turbo Limited was 1.78 and coefficient of variation was 18.30 per cent. The mean value of the current ratio of the Mphasis Limited was 0.08 and co-efficient of variation was 28.28 per cent. Similarly the mean value of the Debt equity ratio of Redinton Limited was 0.82 and co-efficient of variation was 50.06 per cent. On the other hand the mean value of the current ratio of the TCS Limited was 0.00 and co-efficient of variation was 161.02 per cent.

To sum up, among the selected ten study compnies the mean value is high in Lasen and turbo Limited, Redition Limited and Wipro limited, co-efficient of variation is very high in Hexware Limited, TCS Limited and Mindtree Limited during the study period.

\section{I.10. SUGGESTIONS OF THE STUDY}

- The liquidity position majority of the software companies is good with current ratio high and more than industry standard. Solvency position of all software companies is good with high value for investment which is shown in book value and reserves. Majority of the IT companies are not using debt.

- Debt equity ratio is much lesser than industry standard. The major component of cost in IT sector is employee cost the reason is, this is the sector mainly driven by human.

- The selected software companies are the capital intensive in nature but the policy of purchase of fixed assets should be carefully planned and reviewed so that the funds may be properly utilized.

- The selected software companies should try to match the amount of working with the positive trends. The quantum of sales generated should be improved impressively in order to enjoy better operational efficiency of the assets and capital employed.

- The burden of interest has produced a deteriorating effect and reduced the percentage of net profit. It is suggested that a study of productivity and financial efficiency of the software industry of Indian companies. The few companies, which did not follow a definite policy of financing fixed assets, should follow such policy.

\subsection{CONCLUSION OF THE STUDY}

The software industry was passing through rough days and hard times. There have been many periods of adversity, when growth charts have dipped and it has appeared that misfortune will overtake. Today, rapid changes in the World trading system have endangered the stability of the software industry and created an atmosphere of uncertainty and turbulence 
in the industry. But it is also a fact that turbulence is necessary for any change in the system. There is need to bring about technological improvement, structural changes, liberalization from controls and regulations, increased productivities of labour and machine and reliable quality assurance systems to meet the present day needs. If there is insecurity inherent in the globalised economy, there should be also opportunity - opening up of vast markets to Indian software industry that were earlier closed or regulated. Indian software industry is ready to take up this opportunity of free trade and secure its well deserved position in the international tea arena through improved efficient financial management by framing effective policies in raising and utilizing the funds.

\section{REFERENCE}

1. Nirmal, Rajalakshmi. "IT's time for ctrl+alt+delete". The Hindu. Retrieved 26 February 2017.

2. Jump up to: ${ }^{a}$ " nformation technology/business process management (IT-BPM) sector in India as a share of India's gross domestic product (GDP) from 2009 to 2017". NASSCOM. Archived from the original on 20 December 2012. Retrieved 15 December 2012.

3. Singh, Shelley (14 September 2017). "Home market gets attractive for India's IT giants". Retrieved 3 August 2019 - via The Economic Times.

4. "IT industry may become lighthouse for India's growth; here's how many IT firms operate in India". financialexpress.com. Retrieved 3 February 2020.

5. $\quad$ "Indian IT industry looks forward to working together with new US administration". The Economic Times. 8 November 2020. Retrieved 27 November 2020.

6. "Amid IT layoffs, this could be a reason to cheer - Times of India". The Times of India.

7. "Top 50 Emerging Global Outsourcing Cities" (PDF). www.itida.gov.eg. Archived from the original (PDF) on 21 September 2018. Retrieved 22 July 2010.

8. "Special Economic Zones: Profits At Any Cost". Doccentre.net. Archived from the original on 7 September 2010. Retrieved 22 July 2010.

9. "Top 50 Emerging Global Outsourcing Cities" (PDF). www.itida.gov.eg. Archived from the original (PDF) on 21 September 2018. Retrieved 22 July 2010.

10. "Online Journal of Space Communication". Spacejournal.ohio.edu. Retrieved 28 September 2013.

11. Jeevan Jayant Nagarkar, Analysis of Financial Performance of Banks in India, Annual Research Journal of Symbiosis Centre for Management Studies, Pune, Vol. 3, April 2015, ISSN 2348-0661

12. Dr. M. Ravichandran M. Venkata Subramanian, A Study on Financial Performance Analysis of Force Motors Limited, IJIRST -International Journal for Innovative Research in Science \& Technology, Vol.2, Issue 11, April 2016, ISSN (online): 2349-6010 